\title{
The profile of major congenital abnormalities in the United Arab Emirates (UAE) population
}

\author{
L I Al-Gazali, A H Dawodu, K Sabarinathan, M Varghese
}

\begin{abstract}
The aim of this study was to establish the profile of major congenital malformations in the United Arab Emirates (UAE) population which has a high rate of consanguinity. All births with birth weight above $500 \mathrm{~g}$ in the three hospitals in the $\mathrm{Al}$ Ain Medical District of UAE were prospectively studied from January 1992 to January 1994. About $98 \%$ of the births in the district occur in these three hospitals. Detailed family history and clinical and relevant laboratory investigations were recorded in each case. Necropsy was not permitted. The major malformations were classified as multiple or isolated single system abnormalities as well as genetic or non-genetic disorders. Of the 16419 births which occurred during the two year period, $173(10 \cdot 5 / 1000$ births) had major malformations, 90 (52\%) had multiple malformations, and $83(47.97 \%)$ had involvement of a single system. Of the infants with multiple malformations, 43 had recognised syndromes, most of which are autosomal recessive disorders with a high frequency of rare syndromes. Twenty eight (31\%) had chromosomal abnormalities.
\end{abstract} The most common systems involved in infants with isolated single system malformations include gastrointestinal (33), central nervous system (17), and cardiovascular (10). While the consanguinity rate was similar $(57 \% v 54 \%)$, the frequency of first cousin marriages was much higher $(51 \% v 30 \%)$ in the study group compared with the figures for the general population. The consanguinity rate was highest among the syndrome cases, and related parents were more likely to have infants with multiple malformations than an isolated single system abnormality with a relative risk of $1 \cdot 69(95 \%$ CL $1 \cdot 27-2 \cdot 24)$. Genetic factors could be implicated in $116(67 \%)$ of the 173 cases of major malformations and $49(28 \%)$ were potentially preventable. The study suggests that genetic disorders account for a significant proportion of congenital malformations in the UAE and, thus, a genetic service should be provided as part of the preventive care programme.

(f Med Genet 1995;32:7-13)

Congenital malformations are structural abnormalities of prenatal origin that result from defective embryogenesis or deviation from normal development. The pattern and frequency of different congenital abnormalities vary from one country to another depending on geographical, ethnic, and socioeconomic characteristics of the population studied. Such studies are useful for planning health care, including preventive programmes and educational and rehabilitation needs of the population. Recent advances in the diganosis of congenital abnormalities has led to the identification of many more dysmorphic syndromes. In addition, the improvement in prenatal diagnostic techniques has led to an increase in the number of congenital abnormalities which can be prevented. ${ }^{1}$

The population of the United Arab Emirates (UAE) is a mixture of different ethnic groups. The majority are Arab Muslims with a consanguinity rate of $54 \% ; 30 \%$ of marriages are first cousin marriages. ${ }^{2}$ These consanguinity figures were independently reproduced in a pilot study from Al Ain Medical District (AlGazali, unpublished data). Currently, there are no preventive programmes for congenital abnormalities and many women continue to reproduce after the age of 40 years. Attempting to provide genetic counselling for families of children with congenital malformations in this population has highlighted several issues. These included a lack of accurate information on the genetic and non-genetic causes of malformation, and a lack of awareness by both families and the health authorities of the importance of genetic counselling in the prevention of congenital malformations.

The aim of this study was to establish the incidence and pattern of congenital abnormalities in the UAE population, as well as the proportion of anomalies in which genetic factors are implicated, in order to identify the appropriate strategies for prevention.

Materials and methods

A study of 16419 consecutive live and stillbirths over $500 \mathrm{~g}$ birth weight at the three main hospitals in Al Ain, UAE was carried out over a two year period from January 1992 to January 1994. All babies were routinely examined within 48 hours of delivery. All cases of severe congenital abnormalities which were either suspected or diagnosed within the first few days (up to one week) were registered. Only major malformations were included in the study. These were defined as those abnormalities that if uncorrected or uncorrectable significantly impair normal body functions or reduce normal life expectancy. ${ }^{3}$ Congenital dislocation of the hip was not included in this study. The diagnosis of congenital abnormality was based on clinical assessment by an experienced neo- 
Table 1 Major congenital abnormalities in 16419 births in the $U A E$

\begin{tabular}{lrl}
\hline Type & No & Incidence/1000 births \\
\hline Multiple & & \\
Syndromes & 43 & $2 \cdot 61$ \\
Sequences & 12 & $0 \cdot 73$ \\
Chromosomes & 28 & $1 \cdot 70$ \\
Association & 1 & $0 \cdot 06$ \\
Complex & 1 & $0 \cdot 06$ \\
Unknown & 5 & \\
Subtotal & 90 & $5 \cdot 48$ \\
& & \\
Single system & & \\
Cardiovascular & 10 & $0 \cdot 60$ \\
Central nervous system & 18 & $1 \cdot 07$ \\
Gastrointestinal & 33 & $2 \cdot 00$ \\
Respiratory & 2 & $0 \cdot 121$ \\
Genitourinary & 7 & $0 \cdot 42$ \\
Musculoskeletal & 5 & $0 \cdot 30$ \\
Skin & 4 & $0 \cdot 24$ \\
Eye & 2 & $0 \cdot 12$ \\
Tumours & 2 & $0 \cdot 12$ \\
Subtotal & 83 & $5 \cdot 05$ \\
Total & 173 & $10 \cdot 5$ \\
\hline
\end{tabular}

Table 2 Multiple abnormalities in the UAE

\begin{tabular}{|c|c|c|c|}
\hline Type & & No of cases & $\begin{array}{l}\text { Family history } \\
\text { (parent or sib) }\end{array}$ \\
\hline $\begin{array}{l}(1) \\
(A)\end{array}$ & $\begin{array}{l}\text { Syndromes } \\
\text { Autosomal dominant } \\
\text { Holt-Oram } \\
\text { Congenital myotonic dystrophy } \\
\text { Robinow } \\
\text { EDS I } \\
\text { Subtotal }\end{array}$ & $\begin{array}{l}2 \\
1 \\
2 \\
1 \\
6\end{array}$ & $\begin{array}{l}- \\
+ \\
+\end{array}$ \\
\hline (B) & $\begin{array}{l}\text { Autosomal recessive } \\
\text { Joubert } \\
\text { Goldenhar } \\
\text { Larsen } \\
\text { OSMED } \\
\text { Roberts } \\
\text { Wrinkly skin syndrome } \\
\text { EDS VII } \\
\text { SMA } \\
\text { Ophthalmoacromelia } \\
\text { OI + optic atrophy + retinopathy } \\
\text { Osteodysplastic primordial dwarfism II } \\
\text { Osteodysplastic primordial dwarfism I } \\
\text { Kyphomelic dysplasia + tricuspid atresia } \\
\text { Congenital adrenal hyperplasia } \\
\text { Chondrodysplasia punctata } \\
\text { Marden Walker } \\
\text { Cerebro-oculofacioskeletal } \\
\text { Short limb dwarfism ?type } \\
\text { Short rib-polydactyly III } \\
\text { Unknown } \\
\text { Spondylothoracic dysplasia } \\
\text { OI + dysmorphic features } \\
\text { Cystic kidney and ventriculomegaly } \\
\text { Subtotal }\end{array}$ & $\begin{array}{l}2 \\
1 \\
1 \\
1 \\
2 \\
1 \\
2 \\
4 \\
1 \\
1 \\
1 \\
1 \\
1 \\
2 \\
1 \\
1 \\
1 \\
1 \\
1 \\
2 \\
1 \\
2 \\
1 \\
32\end{array}$ & $\begin{array}{l}+ \text { in one } \\
+ \\
+ \\
+ \\
+ \\
+ \\
+ \\
+ \\
+ \\
+ \\
+ \\
+ \\
+ \\
+ \\
+ \\
+ \\
+ \\
+ \\
+ \\
+ \\
+ \\
+\end{array}$ \\
\hline (C) & $\begin{array}{l}\text { Environmental } \\
\text { Congenital rubella }\end{array}$ & 2 & + in one \\
\hline (D) & $\begin{array}{l}\text { Sporadic } \\
\text { Noonan } \\
\text { Sturge Weber }\end{array}$ & $\begin{array}{l}1 \\
1\end{array}$ & $\overline{-}$ \\
\hline$(E)$ & $\begin{array}{l}\text { Unidentified aetiology } \\
\text { Robin sequence + radial aplasia } \\
\text { Total }\end{array}$ & $\begin{array}{r}1 \\
43\end{array}$ & - \\
\hline$(2)$ & $\begin{array}{l}\text { Chromosomal abnormalities } \\
\text { Trisomy } 18 \\
\text { Trisomy } 21 \\
\text { Trisomy } 13 \\
45, \text { X0 (Turner's) } \\
\text { Unbalanced translocation } \\
\text { 5p- (cri du chat) } \\
\text { Total }\end{array}$ & $\begin{array}{r}3 \\
19 \\
1 \\
2 \\
2 \\
1 \\
28\end{array}$ & $\begin{array}{l}- \\
\bar{t} \\
\overline{-} \\
\overline{-}\end{array}$ \\
\hline (3) & $\begin{array}{l}\text { Sequence } \\
\text { Holoproscencephaly } \\
\text { Potter's } \\
\text { Prune belly } \\
\text { Pierre Robin } \\
\text { Amniotic band } \\
\text { Total }\end{array}$ & $\begin{array}{r}2 \\
6 \\
1 \\
2 \\
1 \\
12\end{array}$ & $\begin{array}{l}\overline{-} \\
\overline{-} \\
\overline{-}\end{array}$ \\
\hline (4) & $\begin{array}{l}\text { Association } \\
\text { CHARGE }\end{array}$ & 1 & - \\
\hline$(5)$ & $\begin{array}{l}\text { Complexes } \\
\text { Poland }\end{array}$ & 1 & - \\
\hline (6) & Undefined abnormalities & 5 & \\
\hline
\end{tabular}

natologist or clinical geneticist or both and the London Dysmorphology Database (LDDB) ${ }^{4}$ was consulted when indicated. Chromosome analysis was performed on all babies with multiple abnormalities and dysmorphic features. Other appropriate investigations were performed when indicated. Necropsy was not carried out because it is not allowed. For each case, a detailed pregnancy and family history, including the level of consanguinity, was obtained by interviewing the parents.

Each abnormal baby was classified into one of two major groups.

(1) Isolated abnormalities include abnormalities affecting a single body site.

(2) Multiple abnormalities are those abnormalities that affect more than one body site. These are further divided into:

(A) Syndromes which are further subdivided according to their aetiology into monogenic, chromosomal, environmental, and syndromes of unidentified aetiology.

(B) Associations, which are disorders characterised by the non-random occurrence of several anomalies but which do not constitute a specific syndrome, for example, CHARGE.

(C) Sequences include cases in which the associated anomalies can be interpreted as a consequence of a primary malformation.

(D) Complexes are anomalies of several different structures, all of which lie together in the same body region during embryonic development.

(E) Unrecognisable patterns of multiple defects including patterns of multiple abnormalities that do not fit into any of the above categories.

\section{Results}

There were 173 babies with major congenital abnormalities identified during the two year period, giving an incidence of $10 \cdot 5 / 1000$ births. Six of these were stillbirths and 41 died in the neonatal period. There were 90 babies with multiple congenital abnormalities and 83 babies with isolated malformations. These are summarised in table 1 .

\section{MULTIPLE ABNORMALITIES (90 BABIES)}

(A) Syndromes (43 babies)

The total number of babies who had a recognised syndrome was $43(2 \cdot 6 / 1000)$. Thirty two of these were autosomal recessive, six were autosomal dominant, two had congenital infection, and two were sporadic. One baby had the newly recognised syndrome of radial aplasia and Robin sequence where the aetiology is still uncertain. ${ }^{5}$ The different syndromes are summarised in table 2 .

There were four babies with spinal muscle atrophy presenting with arythrogryposis multiplex, and the diagnosis was confirmed in all of them by muscle biopsy. In one of these babies there was, in addition, bilateral femoral 
fracture noted soon after birth. This baby might have the same syndrome as described by Borochowitz et al. ${ }^{6}$ Of the two cases of Joubert syndrome, one had a similarly affected sib.

There was a set of twins with osteogenesis imperfecta (OI) presenting with multiple fractures and limb deformities, as well as dysmorphic features which included hypertelorism, very short, upturned nose, extremely highly arched palate with thick ridges, and clinodactyly. There was multiple consanguinity in the family and three other affected sibs, with only one surviving to the age of 12 years. The clinical and radiological features in this family did not fit any of the recognised types of OI and collagen studies are in progress to define the type of OI. The baby with Goldenhar syndrome (usually inherited as AD) had another affected sib and both parents were normal and consanguineous and, thus, was included in the AR syndrome.

The infant with wrinkly skin syndrome had two affected sibs and consanguineous parents. The parents of the baby with short rib-polydactyly syndrome III (Verma-Naumoff) had complex consanguinity in the family with a history of three babies dying soon after birth with similar features. Another infant born to these parents had bilateral cataracts and massive intracranial calcification with hepatosplenomegaly and was diagnosed as having congenital infection. There were no surviving children in this particular family.

Many of the recessive syndromes diagnosed were very rare. For example, ophthalmoacromelia was diagnosed in one baby. Another infant had a rare syndrome of osteogenesis imperfecta, optic atrophy, and retinopathy and a similarly affected sib. These cases are reported elsewhere. ${ }^{78}$ There were two cases of microcephalic osteodysplastic primordial dwarfism types I and type II. Both had very complex consanguinity in the family and there was a history of a sib dying with similar features in the former. The case of otospondylomegaepiphyseal dysplasia (OSMED) had two affected sibs and has been previously published. ${ }^{9}$ The baby with chondrodysplasia punctata had two affected sibs and detailed investigation in one of them showed isolated DHAP-AT deficiency. This new peroxisomal disorder has been reported twice previously. ${ }^{10}{ }^{11}$ Other syndromes diagnosed in which there was consanguinity and an affected sib included Larsen syndrome, EDS type VII, and cerebrooculofacioskeletal syndrome. The baby with hydrocephalus and bilateral cystic kidneys had no other associated abnormalities. The family is highly inbred with a history of a previously affected baby and another similarly affected stillbirth who was not included in the study (born after January 1994). This family probably has the same syndrome of ventriculomegaly and cystic kidneys described by Reuss and Den Hollander. ${ }^{12}$ The diagnosis in two babies was uncertain. However, since the parents were consanguineous with a history of three stillbirths who had similar features, these were included with the recessive syndromes. The mother of the infant with congenital myotonic dystrophy had typical features of myotonic dystrophy and two previously affected children. The cases of Robinow syndrome had an affected father and one affected sib.

\section{(B) Chromosome abnormalities (28 cases)}

Abnormal karyotypes were detected in 28 babies as summarised in table 2 . There were 19 cases of Down's syndrome giving an incidence of $1 \cdot 15 / 1000$ which is the same as in other parts of the world. All were of the non-disjunction type. Nine of the mothers were above the age of 35 years.

There was one case of trisomy 13. The mother had a history of previous stillbirth with multiple abnormalities but no cytogenetic analysis was performed. She was found to have a 13;14 translocation.

There were two cases of unbalanced translocation and one case of cri du chat syndrome $(5 p-)$.

\section{(C) Sequence (12 cases)}

Twelve babies had multiple abnormalities as a consequence of a single malformation (table 2). Six had Potter's sequence, four resulting from renal agenesis, one from cystic dysplastic kidney, and one from urethral obstruction. Diagnosis was made by renal ultrasound. Two infants had holoprosencephaly and chromosome analysis was unsuccessful in both.

\section{(D) Association and complexes (2 cases)}

There was one case of CHARGE association and another of Poland anomaly (table 2).

\section{(E) Unrecognised multiple malformations}

Five infants in the study had abnormalities which could not be classified either because the investigations were incomplete or the abnormalities did not conform to any disorder or the syndrome was not known to the authors (table 2).

ISOLATED ABNORMALITIES (83 CASES)

The malformations affecting a single system found in 83 patients are summarised in table 3.

\section{(A) Cardiovascular (10 cases)}

The diagnosis was based on echocardiography in all cases.

\section{(B) Central nervous system (18 cases)}

Anencephaly and meningomyelocele were present in 12 babies. Five cases were diagnosed prenatally by ultrasound late in pregnancy. Two babies had autosomal recessive microcephaly, with a similarly affected sib in one of the cases. There was a case of severe microcephaly and complex brain malformation including polymicrogyria, hypoplasia of the cerebellum and brain stem, with agenesis of corpus callosum. There was a history of three sibs who died 
Table 3 Single system involvement among infants with major malformations

\begin{tabular}{|c|c|c|}
\hline Type & & No \\
\hline$(A)$ & $\begin{array}{l}\text { Cardiovascular } \\
\text { Single ventricle } \\
\text { VSD + PDA } \\
\text { VSD } \\
\text { Transposition of great arteries } \\
\text { Dextrocardia + situs inversus } \\
\text { Complex congenital heart disease } \\
\text { Subtotal }\end{array}$ & $\begin{array}{r}1 \\
2 \\
2 \\
2 \\
1 \\
2 \\
10\end{array}$ \\
\hline (B) & $\begin{array}{l}\text { Central nervous system } \\
\text { Anencephaly } \\
\text { Meningomyelocele } \\
\text { Microcephaly } \\
\text { Cerebrocerebellar lissencephaly and agenesis of } \\
\text { corpus callosum } \\
\text { Polymicrogyria, hypoplasia of cerebellum and } \\
\text { brain stem, and agenesis of corpus callosum } \\
\text { Dandy-Walker malformation } \\
\text { Subtotal }\end{array}$ & $\begin{array}{r}7 \\
5 \\
2 \\
1 \\
1 \\
2 \\
18\end{array}$ \\
\hline (C) & $\begin{array}{l}\text { Genitourinary } \\
\text { Multiple dysplastic kidney } \\
\text { Posterior urethral valve } \\
\text { Hydronephrosis (PUJ obst) } \\
\text { Subtotal }\end{array}$ & $\begin{array}{l}4 \\
1 \\
2 \\
7\end{array}$ \\
\hline (D) & $\begin{array}{l}\text { Musculoskeletal } \\
\text { Distal arythrogryposis } \\
\text { Severe talipes } \\
\text { Craniosynostosis } \\
\text { Focal femoral hypoplasia } \\
\text { Subtotal }\end{array}$ & $\begin{array}{l}1 \\
2 \\
1 \\
1 \\
5\end{array}$ \\
\hline (E) & $\begin{array}{l}\text { Gastrointestinal } \\
\text { Cleft lip and palate } \\
\text { Diaphragmatic hernia } \\
\text { Oesophageal atresia } \pm \text { tracheo-oesophageal } \\
\text { fistula } \\
\text { Imperforate anus } \\
\text { Intestinal obstruction } \\
\text { Omphalocele } \\
\text { Subtotal }\end{array}$ & $\begin{array}{r}10 \\
10 \\
5 \\
4 \\
3 \\
1 \\
33\end{array}$ \\
\hline (F) & $\begin{array}{l}\text { Respiratory } \\
\text { Lung hypoplasia } \\
\text { Laryngomalacia } \\
\text { Subtotal }\end{array}$ & $\begin{array}{l}1 \\
1 \\
2\end{array}$ \\
\hline$(G)$ & $\begin{array}{l}\text { Skin } \\
\text { Epidermolysis bullosa } \\
\text { Peeling skin syndrome } \\
\text { Subtotal }\end{array}$ & $\begin{array}{l}2 \\
2 \\
4\end{array}$ \\
\hline (H) & $\begin{array}{l}\text { Eyes } \\
\text { Microphthalmia }\end{array}$ & 2 \\
\hline (I) & $\begin{array}{l}\text { Tumours } \\
\text { Sacrococcygeal teratoma } \\
\text { Cervical teratoma } \\
\text { Subtotal }\end{array}$ & \\
\hline
\end{tabular}

of similar malformations. The parents were consanguineous and of Omani origin.

\section{(C) Genitourinary (7 cases)}

Four infants had multiple cystic dysplastic kidney, diagnosed by ultrasound. There was a case of posterior urethral valve and two cases of hydronephrosis owing to pelviureteric junction (PUJ) obstruction.

(D) Musculoskeletal (5 cases)

Distal arythrogryposis was present in one baby whose mother was also affected. There was one case each of focal femoral hypoplasia and craniosynostosis and two cases of severe talipes.

\section{(E) Gastrointestinal (33 cases)}

The commonest among these was diaphragmatic hernia (10 cases). All the infants were otherwise normally formed. The defects were confirmed at surgery. There were five cases of oesophageal atresia or tracheo-oeso-
Table 4 Genetic contribution to congenital abnormalities in the $U A E$

\begin{tabular}{lr}
\hline Type & $\begin{array}{r}\text { No of } \\
\text { cases }\end{array}$ \\
\hline Single gene &
\end{tabular}

Total 47

Autosomal recessive

Joubert syndrome

Goldenhar syndrome

Larson syndrome

Spondylothoracic dysplasia

OSMED

Roberts' syndrome

Kyphomelic dysplasia

$\mathrm{CAH}$

Chondrodysplasia punctata

EDS VII

Wrinkly skin syndrome

SMA

OI + optic atrophy + retinopathy

Ophthalmoacromelia

Osteodysplastic primordial dwarfism

Marden Walker syndrome

COFS

OI

Short rib-polydactyly III

Unknown syndrome

Microcephaly

Epidermolysis bullos

Epidermolysis bullosa

Cystic kidney and ventriculomegaly

Cystic kid

Possible AR

Possible $A R$

Short limb dwarfism

Autosomal dominan

Congenital myotonic dystrophy

Holt-Oram

Robinow

EDS

Distal arythrogryposis

Subtotal

Chromosomal abnormalities

Multifactorial

Congenital heart disease ${ }^{14}$

Neural tube defects ${ }^{15}$

Renal agenesis ${ }^{16}$

Severe talipes equinovarus deformity ${ }^{17}$

Holoprosencephaly

Cleft lip/palate ${ }^{19}$

Coronal craniosynostosis ${ }^{20}$

Subtotal

Total

phageal fistula or both, four cases of imperforate anus, and $10 \mathrm{cleft}$ lip/palate. The baby with omphalocele looked normal and had normal chromosomes.

(F) Respiratory (2 cases)

Lung hypoplasia was present in one infant with normal kidneys. The other case was an infant with laryngomalacia who was otherwise normal.

(G) Skin (4 cases)

Two infants had epidermolysis bullosa dystrophica. Two sibs whose parents are consanguineous had Netherton syndrome or peeling skin syndrome. One of them presented as harlequin baby. ${ }^{13}$

\section{(H) Others}

Two infants had simple microphthalmia with no other abnormalities. "TORCH" investigation was normal in both. There was one case each of sacrococcygeal teratoma and cervical teratoma, both proven by histology. 
GENETIC CONTRIBUTION TO CONGENITAL ABNORMALITIES

Genetic factors can be implicated in $116(67 \%)$ of the 173 cases (table 4 ). There were 47 cases caused by a single gene defect $(27 \cdot 1 \%)$ and 38 of these were caused by an AR gene $(21.9 \%)$, two were possibly caused by an AR gene $(1 \cdot 2 \%)$, and seven by an AD gene (4\%). Chromosomal abnormalities accounted for $16 \cdot 1 \%$ (28 babies) and multifactorial inheritance $23.6 \%$ (41 babies) of the cases.

CONSANGUINITY LEVEL

There were 99 babies with consanguineous parents giving a consanguinity rate of $57 \%$ in the study group which is slightly higher than the rate in the general population. ${ }^{2}$

Fifty (51\%) of the 99 babies had first cousin parents compared with $30 \%$ in the general population. ${ }^{2}$ Eight babies had complex consanguinity in the family, these were the twins with OI, and one case each of short rib-polydactyly III syndrome, congenital infection, osteodysplastic primordial dwarfism type I and II, cystic kidney and ventriculomegaly, and an undiagnosed syndrome with three previous stillbirths who were similarly affected.

There was one uncle-niece marriage and three double first cousin marriages. In the remaining 37 cases, the consanguinity level among the parents ranged from first cousin once removed to second cousin to more distant.

The occurrence of consanguinity was 38 $(88 \%)$ in the 43 syndrome cases, $26(55 \%)$ in the other multiple malformation group, and $35(42 \%)$ in those with isolated abnormality. These differences were highly significant $\left(\chi^{2}=\right.$ 24.06, df 2, p<0.0001). Similarly, consanguineous parents were more likely to have infants with multiple malformations than isolated abnormalities with a relative risk of 1.69 $(95 \% \mathrm{CL}=1 \cdot 27-2 \cdot 24)$.

HOW MANY ABNORMALITIES WERE POTENTIALLY PREVENTABLE?

Nine babies with Down's syndrome whose mothers were above 35 years of age could have been diagnosed antenatally using the triple test followed by chorionic villus biopsy (CVB) or amniocentesis. Similarly, the 12 infants with neural tube defects could have been detected in utero using $\alpha$ fetoprotein and ultrasonography. The case of trisomy 13 whose mother had a 13;14 translocation and a history of stillbirth with malformation should have had CVB or amniocentesis.

There were six cases with a positive family history and abnormalities that are detectable by antenatal ultrasound. These include the baby with microcephaly and complex CNS malformation (three sibs affected), Joubert syndrome (one sib affected), short rib-polydactyly III (three sibs affected), the twins with OI (three sibs affected), and the baby with cystic kidneys and ventriculomegaly.

Three other cases with previously affected sibs had disorders that could be diagnosed prenatally using biochemical or molecular stud- ies; these include CAH (one sib affected), congenital myotonic dystrophy (mother and two sibs), and the baby with chondrodysplasia punctata with isolated deficiency of DHAPAT.

Furthermore, genetic counselling could have changed the reproductive decision of the parents of 18 babies with previously affected sibs and abnormalities which are not yet detectable by prenatal testing.

Therefore, the total number of abnormalities which were potentially preventable was 49 $(28 \%)$.

\section{Discussion}

The incidence of congenital abnormalities in this study was $10 \cdot 5 / 1000$ which is comparable to or even slightly less than studies from other countries. ${ }^{2122}$ However, this figure could be an underestimate since only $43 \%$ of all congenital abnormalities are diagnosed at birth, ${ }^{23}$ and some internal malformations are only recognised by necropsy which is not permitted here. It is of interest that the incidence of abnormalities caused by a single gene defect in this study was high (27\%). Other studies found an incidence of such abnormalities to range from 7 to $25 \% .{ }^{24}{ }^{25}$ This is probably because of racial differences of the population studied, for example the high incidence of single gene disorders in Holmes's study (25\%) was the result of the common prevalence of postaxial polydactyly type $b$ in the black population. In fact, if this abnormality is excluded from the data in that study, the incidence of single gene mutations drops to $8 \% . .^{24} 25$

The high incidence of single gene disorders in our study is accounted for by the incidence of autosomal recessive abnormalities in this population $(21.9 \%)$. If the two possibly recessive disorders were included, the incidence of autosomal recessive abnormalities will increase to $23 \%$. A similar study from Abu Dhabi found the incidence of congenital abnormalities to be $12 \cdot 9 / 1000$ with a relatively high frequency of rare disorders. ${ }^{26}$

The high incidence of major malformations caused by rare recessive genes is probably related to the high level of consanguinity in the population of UAE. Although the rate of consanguinity in the study group was only slightly higher than that of the general population, the frequency of first cousin marriages of $51 \%$ was particularly high when compared with $30 \%$ in the general population. ${ }^{2}$ In addition, the consanguinity level was highest in the syndrome group (88\%). This group consisted mainly of the AR syndromes.

Studies of congenital malformations in different parts of the world have shown that the risk for malformation in first cousin marriages increases to 5 to $8 \%$ compared to a 2 to $3 \%$ frequency in the general population. ${ }^{27-32}$ Jaber et $a l^{32}$ found a significant increase in the incidence of major malformation in relation to the closeness of the parental relationship in an Israeli Arab village $15.8 \%$ in the offspring of first cousin marriage compared to $8.3 \%$ in intra-village non-related marriages and $5 \cdot 8 \%$ 
in the offspring of intervillage marriages). In our series, although the very high level of consanguinity, particularly first cousin marriages, did not seem to increase the overall incidence of congenital malformation diagnosed in the first week of life, there was a definite increase in the incidence of malformation caused by rare recessive genes. Further, the parents of infants with inherited syndromes and multiple malformations group were about twice as likely to be related than the parents of infants with isolated or single system abnormalities.

It is well known that the risk of a child having a recessively inherited condition is higher if the parents are related, and the more closely related the parents are, the higher the risk. These observations were exploited by human geneticists to devise a method to map rare recessive traits by linkage analysis. ${ }^{33}$ The concept of homozygosity mapping, which was initially suggested by $\mathrm{Smith}^{34}$ and later elaborated by Lander and Bostein, ${ }^{35}$ has been successfully used to map many rare recessive disorders. ${ }^{36-39}$ Since the majority of the congenital abnormalities in this series are caused by rare recessive genes, and the level of first cousin marriages and complex consanguinity are high among the parents of affected children, it may be useful for future research in the UAE to evaluate such families further in order to map the genes for these recessive syndromes. This will be important in the prevention of these disorders.

Twenty-eight percent of the abnormalities in this study were preventable using pregnancy screening for neural tube defect, screening older mothers for Down's syndrome, or by using the family history as an indicator for genetic counselling and prenatal diagnosis.

Czeizel $e t a l^{1}$ showed that preventive methods are currently available for $70 \%$ of congenital abnormality entities and that $60 \%$ of these developmental defects are preventable. In addition, other reports suggest that 70 to $80 \%$ of severe congenital abnormalities may be detected by routine fetal anomaly scanning by trained non-medical operators with modern equipment. ${ }^{40}$ If such approaches become widely used, the proportion of congenital abnormalities that could be prevented would increase considerably.

There are no preventive programmes in the UAE and genetic services are inadequate. The high incidence of abnormalities with a high recurrence risk (single gene) in this study indicates that there is a need to develop a comprehensive preventive programme for congenital abnormalities in this country. Apart from the routine maternal care in pregnancy, there should be a special and sensitive educational programme about the genetic consequences of consanguineous marriage. Genetic counselling supported by the availability of antenatal screening and prenatal diagnostic technology when appropriate should be an essential component of such a programme. This should form the basis of a community based genetic service which is an integral part of preventive medical care.

In conclusion, this prospective study has pro- duced a detailed analysis of the pattern of congenital malformation in a Middle Eastern medical district. The high incidence of genetic factors in the causation of the malformation suggests an urgent need for a comprehensive genetic service as part of the health care programme.

1 Czeizel A, Intody Z, Modell B. What proportion of congenital abnormalities can be prevented. BMF 1993;306: 499-503.

2 Fahmy NA, Benson PF, Al-Garrah DB. Consanguinity in the UAE: prevalence and analysis of some risk factor. Emir Med f 1993;1(suppl):39-41.

3 Aylsworth AS. Genetic counselling for patients with birth defects. Pediatr Clin North Am 1992;39:229-53.

Winter RM, Barraitser M. London Dysmorphology Database. f Med Genet 1987;24:509-10.

5 Bruce A, Winship I. Radial ray defect and Robin sequence: a new syndrome. Clin Dysmorphol 1993;2:241-4.

6 Borochowitz Z, Glick B, Blazer S. Infantile spinal muscular atrophy (SMA) and multiple congenital fractures in sibs: a lethal new syndrome. F Med Genet 1991;28:345-8.

7 Al-Gazali LI, Sabarinathan K, Khidir A. Microphthalmia and distal limb abnormalities in a child of consanguineous parents.Clin Dysmorphol 1994;3:258-62.

8 Al-Gazali LI, Sabarinathan K, Nair K. A syndrome of osteogenesis imperfecta, optic atrophy, retinopathy and severe developmental delay. Clin Dysmorphol 1994;3:55-62.

9 Al-Gazali LI, Lytle W. Otospondylomega epiphyseal dysplasia (OSMED): report of three sibs and review of the plasia (OSMED): report of three sibs and
literature. Clin Dysmorphol 1994;3:46-54.

10 Wanders RJA, Schemacher H, Heikoop J, Schutgens RB, Tager JM. Human dihydroxyacetonephosphate acyltransferase deficiency: a new peroxisomal disorder. $\mathcal{f}$ Intransferase deficiency: a new peroxis
herited Metabol Dis 1992;15:389-41.

11 Barr DGD, Kirk JM, Al Howasi M, Wanders RJ, Schutgens RBH. Rhizomelic chondrodysplasia punctata with isolate DHAP-AT deficiency. Arch Dis Child 1993;68:415-17.

12 Reuss A, Den Hollander JC. Prenatal diagnosis of cystic kidney disease with ventriculomegaly: a report of six cases in two related sibships. Am F Med Genet 1989;33:385-9.

13 Lestringant G, Hertecant J, Bossaert Y, Abdulrazzaq Y, Frossard P. A harlequin fetus evolving into a ComelNetherton/peeling skin type B syndrome. Abstracts of the Academy of Dermatology, San Francisco, 1994.

14 Harper PS. Practical genetic counselling. 4th ed. London: Butterworth Heinemann, 1993:241.

15 Harper PS. Practical genetic counselling. 4th ed. London: Butterworth Heinemann, 1993:177.

16 Carter CO, Evans K, Pescia G. A family study of renal agenesis. F Med Genet 1979;16:176-88.

17 Wang J, Palmer RM, Chung S. The role of major genes in club foot. Am $\mathcal{f}$ Hum Genet 1988;42:772-6.

18 Benke PJ, Cohen MM. Recurrence of holoprosencephaly in families with family history. Clin Genet 1983;24:324-8.

19 Harper PS. Practical genetic counselling. 4th ed. London: Butterworth Heinemann, 1993:212-13.

20 Carter CO, Till K, Fraser R. A family study of craniosynostosis with probable recognition of a distinct syndrome. $\mathcal{f}$ Med Genet 1982;19:280-5.

21 Stevenson AC, Johnson HA, Stewart MP, Golding ARE. Congenital malformations. A report of a study of series Congenital malformations. A report of a study of series
of consecutive births in 24 centres. Bull WHO 1966; 34(suppl):25-9, 90-2.

22 Congenital malformation worldwide. $A$ report from the International Clearinghouse of Birth Defects Monitoring System. ternational Clearinghouse of Birth

23 McIntosh R, Merrit K, Richards M, Samrels M, Bellows $M$. The incidence of congenital malformations. A study $M$. The incidence of congenital malformations.

24 Van Regemorter J, Dodion J, Druart C, et al. Congenital malformations in 10,000 consecutive births in a university malformations in 10,000 consecutive births in a university hospital: need for genetic counsell

25 Holmes LB. Inborn errors of morphogenesis: a review of localized hereditary malformations. N Engl f Med 1974; 291:763.

26 Al-Jawad ST, Shubbar AI, Khafaji NA, Kholeif SA, Lane SM, Moore DK. A survey of serious congenital morphological abnormalities in Abu Dhabi. Ann Trop Paediatr 1988;8:76-9.

27 Naderi $M$. Congenital abnormalities in newborns of consanguineous and non-consanguineous parents. Obstet Gynecol 1979;53:195-9.

28 Gatrad ARE, Read AP, Watson GH. Consanguinity and complex cardiac anomalies with situs ambiguous. Arch Dis Child 1984;59:242-5.

29 Radha RD, Apaji RN, Bittles AH. Inbreeding and the incidence of childhood genetic disorders in Karnataka, South India. $\mathcal{F}$ Med Genet 1987;24:362-5.

30 Magnus P, Berg K, Bjerkedal T. Association of parental consanguinity with decreased birthweight and increased rate of early death and congenital malformation. Clin Genet $1985 ; 28: 342-5$.

31 Shami SA, Schmitt LH, Bittles AH. Consanguinity related prenatal and postnatal mortality of the population of seven Pakistani Punjab cities. F Med Genet 1989;26:267-71.

32 Jaber L, Merlob P, Bu X, Rotter JT, Shohat M. Marked parental consanguinity as a cause for increased major 
malformation in an Israeli Arab community. $A m \mathcal{F} \mathrm{Med}$ Genet 1992;44:1-6.

33 Farrall M. Homozygosity mapping: familiarity breeds debility. Nature Genet 1993;5:107-8.

34 Smith CAB. The detection of linkage in human genetics. $\mathcal{f}$ $R$ Stat Soc [B] 1953;15:153-92.

35 Lander E, Bostein D. Homozygosity mapping: a way to map human recessive traits with the DNA of inbred children. Science 1987;236:1567-70.

36 Frydman M, Bonne-Tamir B, Farrer LA, et al. Assignmen of the gene for Wilson disease to chromosome 13: linkage to the esterase D locus. Proc Natl Acad Sci USA 1985;82: 1819-21.
37 Gilliam TC, Brzustowicz LM, Castilla LH, et al. Genetic homogeneity between acute and chronic forms of spinal muscular atrophy. Nature 1990;345:823-5.

38 Pras E, Aksentijevich I, Gruberg L, et al. Mapping of a gene causing familial Mediterranean fever to the short arm of chromosome 16. N Engl f Med 1992;326:1509-13.

39 Ben Othmane $\mathrm{K}$, Ben Hamida $\mathbf{M}$, Pericak-Vance MA, $e$ al. Linkage of Tunisian autosomal recessive Duchennelike muscular dystrophy to the pericentromeric region of chromosome 13q. Nature Genet 1992;2:315-17.

40 Luck C. Value of routine ultrasound scanning at 19 weeks: a four year study of 8,849 deliveries. $B M \mathcal{F} 1992 ; 304$. 1474-8. 